\title{
Endoscopic Ultrasound-Guided Vascular Therapy for Portoduodenal Fistula
}

\author{
Tanyaporn Chantarojanasiri', Apichet Sirinawasatien ${ }^{1}$, Chalermrat Bunchorntavakul', Aroon Siripun ${ }^{1,2}$, Sa-ard Treepongkaruna ${ }^{3}$ \\ and Thawee Ratanachu-ek ${ }^{3}$ \\ ${ }^{1}$ Department of Internal Medicine, Rajavithi Hospital, Bangkok, ${ }^{2}$ Department of Internal Medicine, Bangkok Hospital, Bangkok, ${ }^{3}$ Department \\ of Surgery, Rajavithi Hospital, Bangkok, Thailand
}

Portoenteric fistula is a rare cause of massive upper gastrointestinal bleeding. Most cases can be treated with radiointervention or surgery, but portoenteric fistula is associated with a high mortality. We reported a case of intermittent massive upper gastrointestinal bleeding in a 33-year-old man with cholangiocarcinoma who underwent surgical resection followed by chemoradiation. A portoduodenal fistula due to chronic duodenal ulceration was identified. The bleeding was successfully controlled by endoscopic ultrasound-guided coil placement through the duodenal bulb using the anchoring technique. Follow-up endoscopy and computed tomography scan showed multiple coil placements between a part of the portal vein and the duodenal bulb without any evidence of portal vein thrombosis. There were no complications, and bleeding did not recur during the 8-month follow-up period. Clin Endosc 2020;53:750-753

Key Words: Endosonography; Gastrointestinal hemorrhage; Vascular fistula

\section{INTRODUCTION}

Upper gastrointestinal bleeding due to a vascular-enteric fistula is uncommon but fatal. In most of the reported cases, the connection between the arterial and enteric wall developed after an endovascular intervention, surgery, or chronic inflammation. ${ }^{1}$ A portoduodenal fistula is rare and usually reported in association with duodenal ulceration after surgery ${ }^{2-4}$ as a consequence of a chronic ulcer ${ }^{5,6}$ or in association with a portal vein aneurysm after pancreaticoduodenectomy. ${ }^{7}$ All cases presented with upper gastrointestinal bleeding and were treated with surgery or endovascular intervention. We report-

Received: August 28, 2019 Revised: November 7, 2019

Accepted: December 2, 2019

Correspondence: Tanyaporn Chantarojanasiri

Division of Gastroenterology, Department of Internal Medicine, Rajavithi Hospital, 2 Phayathai Road, Ratchathewi District, Bangkok 10400, Thailand Tel: +66-2-354-8108, Fax: +66-2-354-8146, E-mail: chtunya@gmail.com ORCID: https://orcid.org/0000-0001-5781-8696

(cc) This is an Open Access article distributed under the terms of the Creative Commons Attribution Non-Commercial License (http://creativecommons.org/ licenses/by-nc/3.0) which permits unrestricted non-commercial use, distribution, and reproduction in any medium, provided the original work is properly cited. ed a case of a portoduodenal fistula after hepatic resection that was treated with endoscopic ultrasound (EUS) intervention.

\section{CASE REPORT}

We report a case of a 33-year-old male who was diagnosed with hilar cholangiocarcinoma and underwent right hepatectomy and para-aortic lymph node dissection three years prior to this diagnosis. The surgical staging was T4N1M1 with pancreatic and pulmonary involvement; he received adjuvant chemotherapy and concurrent chemoradiation. During the follow-up, he had recurrent aortocaval lymph node metastasis, so additional boosted small field radiotherapy (200 cGy, 25 cycles) was administered. He was well until 6 months after radiotherapy. Then, he showed symptoms of intermittent massive upper gastrointestinal bleeding with hemorrhagic shock, requiring intensive care unit admission. In each episode, he developed hematemesis with hematochezia; his hemoglobin level decreased from a baseline of $13 \mathrm{~g} / \mathrm{dL}$ to $8.4 \mathrm{~g} / \mathrm{dL}$ with acute kidney injury.

After adequate resuscitation, emergency esophagogastro- 
duodenoscopy (EGD) was performed, and a duodenal ulcer with visible suture material at the ulcer base was observed (Fig. 1). Intermittent active bleeding from the ulcer bed was observed, but no visible vessel was identified as the source of bleeding. Due to highly active bleeding that obscured the endoscopic view, hemostatic clips were placed adjacent to the bleeding point, and the patient underwent emergency angiography. Angiography did not show any extravasation or vascular abnormalities adjacent to the hemostatic clips. The patient then underwent emergency computed tomography (CT), which showed the portal vein attached to the duodenal bulb without active extravasation (Fig. 2). EUS was performed, and the connection between the portal vein to the base of the ulcer was observed. After discussion with the radiointerventionist and hepato-pancreatico-biliary surgeons, endoscopic intervention was considered. EUS-guided coil placement, using 9-mm and 5-mm helical coils (Tornado ; Cook Medical, Bloomington, IN, USA), was performed in three separate episodes, providing anchoring between the underlying vessel and duodenal mucosa (Fig. 3). The anchoring of the coil was performed by slowly withdrawing the needle during coil

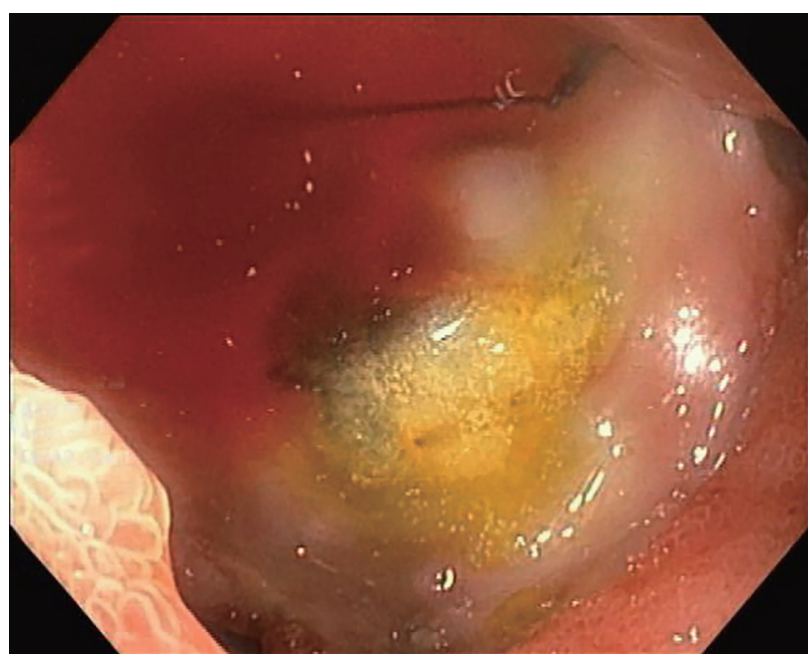

Fig. 1. Endoscopic view showing active bleeding from an ulcer at the duodenal bulb. insertion, leaving $1 \mathrm{~cm}$ of the coil inside the duodenal lumen (Fig. 4). The bleeding stopped, and follow-up EGD showed the visible coil at the ulcer base (Fig. 4). Additional glue spray and hemospray were added on the friable ulcer surface during follow-up endoscopic sessions. Follow-up CT scan of the upper abdomen showed multiple coils at the fistula area (Fig. 5). No recurrent bleeding was observed during the 8-month follow-up period.
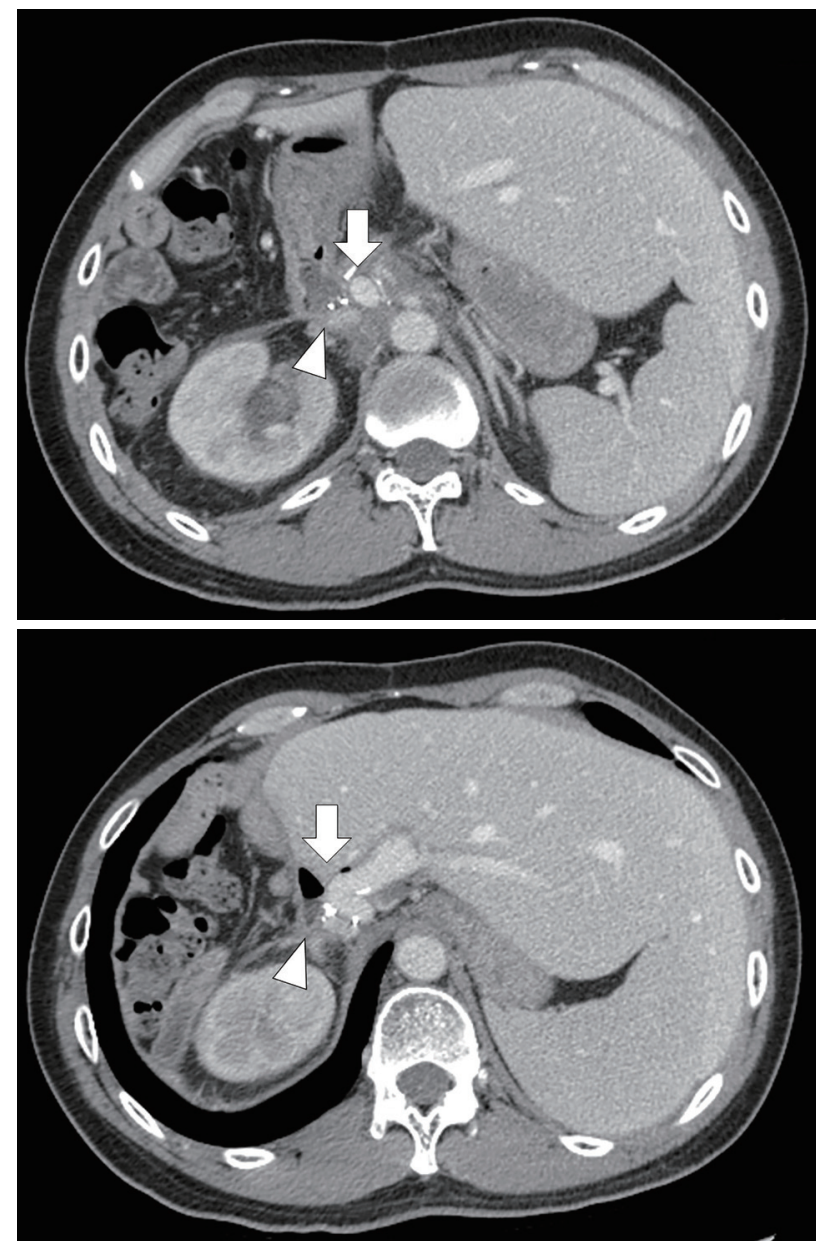

Fig. 2. Computed tomography scan showing portal vein (arrow) attached to about the duodenal bulb (arrowhead)
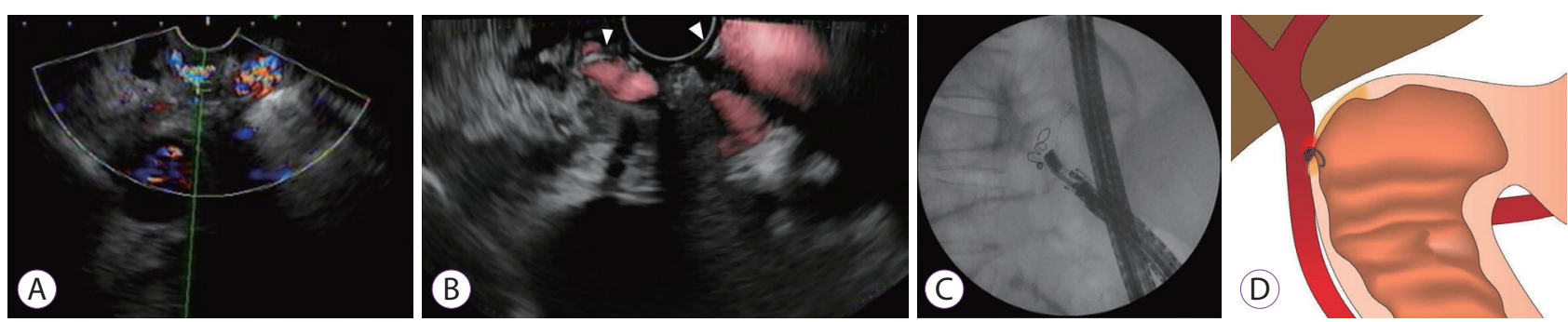

Fig. 3. Endoscopic ultrasound (EUS) images showing the portal vein attached to the base of the ulcer (A). EUS-guided coil embolization was performed (B, coil marked with arrowhead). Fluoroscopic image shows the coil placement without migration (C). The fine aspiration needle was withdrawn during coil deployment, leaving the distal part of the coil anchored against the duodenal wall (D). 


\section{DISCUSSION}

We reported about a 33-year-old patient who presented with bleeding from a portoenteric fistula three years after hepatectomy and chemoradiation. The duodenal ulcer causing the portoduodenal fistula was identified as the source of bleeding and was successfully treated with EUS-guided coil placement using the anchoring technique to prevent distal embolization into the portal vein; this technique was similar to the technique used in EUS-guided coil embolization of gastric varices. ${ }^{8}$

Bleeding from a portoduodenal fistula is rare, with only

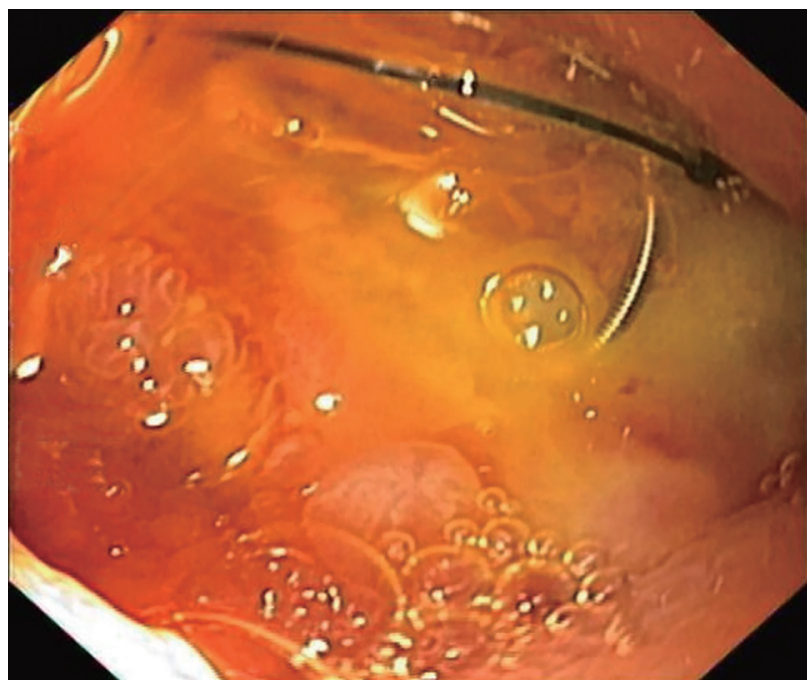

Fig. 4. Follow-up endoscopy showing friable ulcer with a visible coil on the ulcer base. a few cases ever reported. In 2003, Povoski et al. ${ }^{4}$ reported a similar case of a duodenal ulcer resulting in a portoduodenal
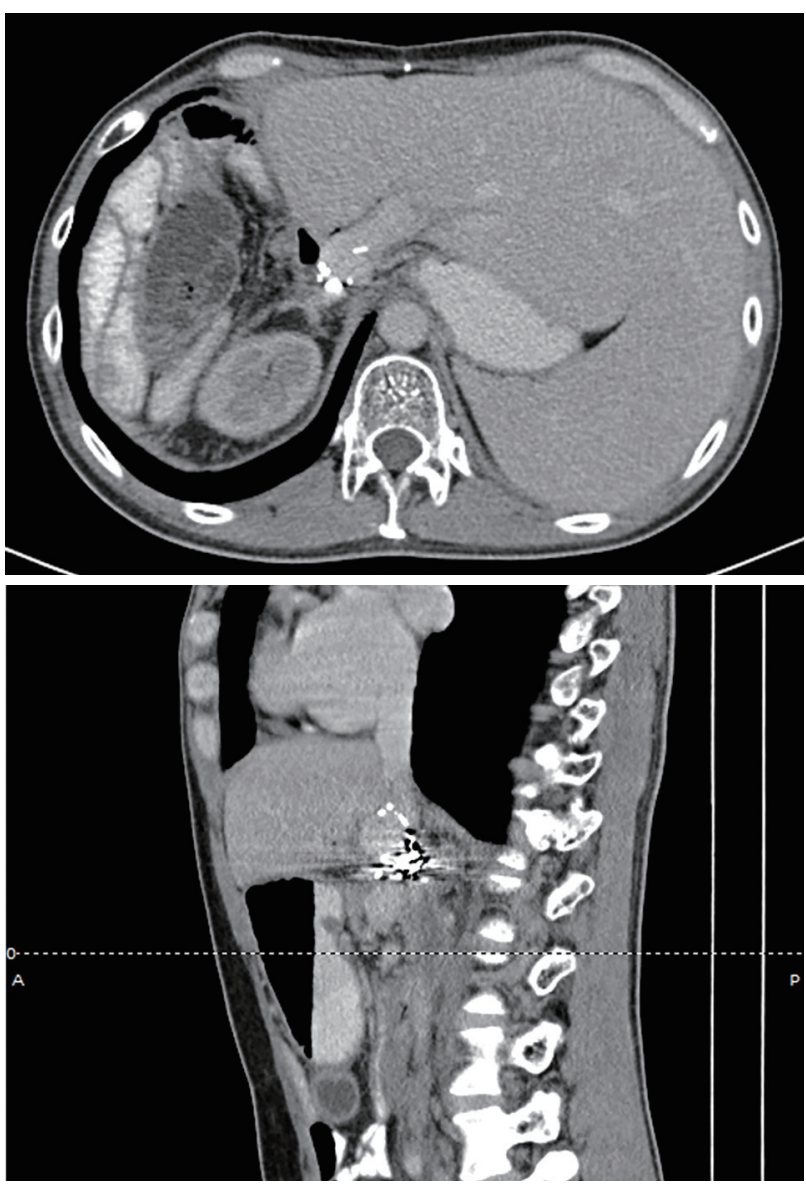

Fig. 5. Follow-up computed tomography scan showing coil embolization at the portoenteric fistula.

Table 1. Case Reports Involving Portoduodenal Fistula

\begin{tabular}{|c|c|c|c|}
\hline Study & Underlying disease & Treatment & Outcome \\
\hline Soares et al. $(1996)^{6}$ & Peptic ulcer, taking NSAIDs & Surgical operation & Died \\
\hline Povoski et al. $(2003)^{4}$ & $\begin{array}{l}\text { Extrahepatic bile duct tumor, under- } \\
\text { went resection and brachytherapy, } \\
\text { history of taking NSAIDs }\end{array}$ & Surgical operation & Survived \\
\hline Kinoshita et al. $(2006)^{3}$ & $\begin{array}{l}\text { Cholangiocarcinoma, underwent } \\
\text { extended right hepatectomy }\end{array}$ & $\begin{array}{l}\text { Endoscopic hemostasis by hemoclips } \\
\text { and transarterial embolization }\end{array}$ & $\begin{array}{l}\text { Died due to uncontrolled bleed- } \\
\text { ing }\end{array}$ \\
\hline Burke et al. $(2007)^{7}$ & $\begin{array}{l}\text { Pancreatic mucinous tumor, under- } \\
\text { went pancreaticoduodenectomy with } \\
\text { pancreaticojejunal anastomotic leak }\end{array}$ & $\begin{array}{l}\text { Transhepatic portal vein angioplasty } \\
\text { followed by surgical repair }\end{array}$ & $\begin{array}{l}\text { Died due to uncontrolled bleed- } \\
\text { ing }\end{array}$ \\
\hline Fujiki et al. $(2012)^{2}$ & $\begin{array}{l}\text { Cholangiocarcinoma, underwent right } \\
\text { hepatectomy }\end{array}$ & $\begin{array}{l}\text { Endoscopic epinephrine injection } \\
\text { and vascular embolization }\end{array}$ & $\begin{array}{l}\text { Died due to uncontrolled bleed- } \\
\text { ing }\end{array}$ \\
\hline Masuda et al. $(2013)^{5}$ & Duodenal ulcer & Surgical resection & $\begin{array}{l}\text { Died due to portal vein throm- } \\
\text { bosis and liver dysfunction }\end{array}$ \\
\hline Our report (2019) & $\begin{array}{l}\text { Cholangiocarcinoma, underwent hepa- } \\
\text { tectomy and chemoradiation }\end{array}$ & $\begin{array}{l}\text { Endoscopic ultrasound-guided coil } \\
\text { embolization }\end{array}$ & Survived \\
\hline
\end{tabular}

NSAIDs, non-steroidal anti-inflammatory drugs. 
fistula after bile duct resection and radiotherapy (Table 1).-7 The onset of bleeding was two years after surgery, similar to our case. In this report, a surgical procedure that may have changed the anatomical connection between the portal vein and duodenum may have contributed to fistula formation via chronic duodenal ulceration. Conversely, the role of radiation cannot be ruled out because earlier cases of penetrating peptic ulcers causing portoduodenal fistulas were also published. Using proton pump inhibitors for stress-related ulcer prevention after surgery, the incidence of complicated peptic ulceration decreased. ${ }^{9}$ We hypothesized that in our case, the surgery might have caused the anatomical alteration that caused the portal vein and the duodenal wall to come closer in proximity; the repeated local irradiation might have also caused poor healing of the tissue. Because the bleeding originated from the portal system, most of the other case reports chose to treat with portal vein stenting performed by a radiointerventionist or with surgery; however, portal vein stents were not available in our country at the time of this event. Furthermore, surgery might be associated with very high morbidity or mortality owing to the post-radiation effect on the surrounding tissue.

Coil embolization has been used for the treatment of intracranial aneurysms for decades. ${ }^{10}$ EUS-guided coil embolization, in particular, has been used for the treatment of vascular lesions, especially gastric varices. ${ }^{11}$ To minimize the risk of coil migration, several techniques, including anchoring the coil with gastrointestinal mucosa, have been applied. ${ }^{12}$ Until now, this is the first case that reported the use of EUS-guided coil insertion to treat a portoduodenenal fistula. This technique was less invasive, and the procedure could be performed without the need for endoscopic view, especially during active bleeding. Nevertheless, there were still concerns regarding the risk of coil migration or subsequent portal vein thrombosis. To prevent these problems, coil insertion was performed under fluoroscopy, and the anchor technique was used to fix the coil. Portal vein thrombosis was not observed in our case.

In summary, we reported a case with a portoduodenal fistula, causing massive upper gastrointestinal bleeding, who was treated with EUS-guided coil placement.
Conflicts of Interest

The authors have no financial conflicts of interest.

ORCID

Apichet Sirinawasatien: https://orcid.org/0000-0001-5165-0888 Chalermrat Bunchorntavakul: https://orcid.org/0000-0002-8842-032X Aroon Siripun: https://orcid.org/0000-0001-5045-0884

Sa-ard Treepongkaruna: https://orcid.org/0000-0003-4053-4333

Thawee Ratanachu-ek: https://orcid.org/0000-0002-8579-1547

\section{REFERENCES}

1. Lemos DW, Raffetto JD, Moore TC, Menzoian JO. Primary aortoduodenal fistula: a case report and review of the literature. J Vasc Surg 2003;37:686-689.

2. Fujiki M, Ramirez JR, Aucejo FN. Duodenoportal fistula resulting from peptic ulcer after extended right hepatectomy for cholangiocarcinoma. Am Surg 2012;78:E154-E155.

3. Kinoshita H, Takifuji K, Nakatani Y, Tani M, Uchiyama K, Yamaue H. Duodenoportal fistula caused by peptic ulcer after extended right hepatectomy for hilar cholangiocarcinoma. World J Surg Oncol 2006;4:84.

4. Povoski S, Shammảa J. Fistula involving portal vein and duodenum at the site of a duodenal ulcer in a patient after previous extrahepatic bile duct resection and brachytherapy. Dig Surg 2003;20:53-55.

5. Masuda T, Yano F, Aoki H, Mitsumori N, Omura N, Yanaga K. A case of a portoenteric fistula due to a duodenal ulcer. Journal of Abdominal Emergency Medicine 2013;33:1165-1168.

6. Soares MA, Wanless IR, Ambus U, Cameron R. Fistula between duodenum and portal vein caused by peptic ulcer disease and complicated by hemorrhage and portal vein thrombosis. Am J Gastroenterol 1996;91:1462-1463.

7. Burke CT, Park J. Portal vein pseudoaneurysm with portoenteric fistula: an unusual cause for massive gastrointestinal hemorrhage. Semin Intervent Radiol 2007;24:341-345.

8. Baron TH, Song LM, Ross A, Tokar JL, Irani S, Kozarek RA. Use of an over-the-scope clipping device: multicenter retrospective results of the first U.S. experience (with videos). Gastrointest Endosc 2012;76:202-208.

9. Strand DS, Kim D, Peura DA. 25 years of proton pump inhibitors: a comprehensive review. Gut Liver 2017;11:27-37.

10. Koebbe CJ, Veznedaroglu E, Jabbour P, Rosenwasser RH. Endovascular management of intracranial aneurysms: current experience and future advances. Neurosurgery 2006;59:S93-S102; discussion S3-S13.

11. Fujii-Lau LL, Law R, Wong Kee Song LM, Levy MJ. Novel techniques for gastric variceal obliteration. Dig Endosc 2015;27:189-196.

12. Bapaye A, Dubale N, Mahadik M, Bharadwaj T. EUS guided coil embolization of giant gastric varices and modified technique to prevent distant embolization. Gastrointest Endosc 2017;85(5 Suppl):AB139. 